\title{
Value-Driven Health Care: Proceed With Caution
}

\author{
Kenneth S. Fink, MD, MGA, MPH
}

Given the context of continually increasing health care expenditures, value-driven health care is a concept that is gaining attention. Optimizing quality and efficiency provides greatest value, and aligning financial incentives through, for example, pay-for-performance programs, is a strategy growing in popularity. Such programs lack evidence of effectiveness for improving health outcomes and may have the potential limitations of opportunity costs and further disenfranchisement of vulnerable populations. However our current health care system is unsustainable, and fundamental reform is indicated. Financial incentives may prove to be an effective strategy for improving quality and efficiency and deserve exploration, but pay-for-performance programs warrant further evaluation, with attention directed to identify and respond to any adverse unintended effects of these programs. ( $\mathrm{J}$ Am Board Fam Med 2008; 21:458-460.)

Increases in health care sector expenditures continue to outpace nearly every other sector of the economy. ${ }^{1}$ In addition to greater expenditures by the government, which now pays nearly half of total health care spending, ${ }^{1}$ employers are paying more for health care, often at the expense of workers' wages. $^{2}$ These rising costs make obtaining health care more challenging for the underinsured and uninsured and, before the subprime mortgage collapse, health care costs were the leading cause of personal bankruptcy. ${ }^{3}$ With the release of the 2007 National Healthcare Quality Report by the Agency for Healthcare Research and Quality, ${ }^{4}$ we are reminded that our health care investment has a poor return. In response to these alarming trends, many stakeholders are advocating for increased health

This article was externally peer reviewed.

Submitted 30 April 2008; revised 29 June 2008; accepted 1 July 2008.

From the Department of Family Medicine, Uniformed Services University of the Health Sciences, Bethesda, MD.

Funding: none.

Conflict of interest: Dr. Fink was previously the Centers for Medicare and Medicaid Services Region 10 Chief Medical Officer and regional lead for its Value Driven Health Care effort.

Corresponding author: Kenneth S. Fink, MD, MGA, MPH, Med-QUEST Division, State of Hawaii Department of $\mathrm{Hu}-$ man Services, P.O. Box 700190, Kapolei, HI 96709-0190 (E-mail: kfink@medicaid.dhs.state.hi.us).

\section{See Related Commentary on Page 370.}

care value by doing more of what does work and less of what does not. However, incentivizing quality and efficiency may result in unintended consequences. ${ }^{5}$ As incentive programs mature, attention must be directed to identifying and responding to any adverse unintended effects of these programs.

Quality and efficiency are 2 terms used when assessing value in health care. The Institute of Medicine (IOM) defines quality as "the degree to which health services for individuals and populations increase the likelihood of desired health outcomes and are consistent with current professional knowledge." In other words, quality represents the consistency of the delivery of effective health care. The IOM defines efficiency as "avoiding waste, including waste of equipment, supplies, ideas, and energy." ${ }^{77}$ Efficiency is often considered the ratio of output to input and might be reflected as health outcome per resources consumed. ${ }^{8}$ Quality and efficiency are independent factors within a system and the goal is to optimize both, thereby achieving greatest value.

Improving quality and efficiency requires measurement and this has resulted in a flurry of activity surrounding quality measures. Between 2004 and 2007 , the number of quality measures on the $\mathrm{Na}$ tional Quality Measures Clearinghouse increased by over $60 \% .{ }^{9}$ In 2002 the National Quality Forum (NQF) had zero ambulatory quality indicators; in 2007 the NQF had 122, of which 102 were process, 11 were outcome, and 9 were patient experience. ${ }^{10}$ The NQF uses a consensus-based process to endorse measures. The elements of the scientific ac- 
ceptability criterion are precise specifications, reliability, validity, discriminating real differences in performance, adaptability, adequacy of risk adjustment, and consistent evidence linking process to outcome. ${ }^{10}$

However, it is not always clear that process measures lead to improved health outcomes. For example, the NQF-endorsed hospital heart failure measures, also used by the Centers for Medicare and Medicaid Services (CMS), include evaluation of left ventricular systolic function and provision of discharge instructions, ${ }^{10}$ but a large retrospective cohort study found that, when adjusted, neither of these measures was significantly associated with reducing mortality or rehospitalization. ${ }^{11}$ Prescribing an angiotensin-converting enzyme inhibitor or angiotensin receptor blocker and prescribing a betablocker at discharge were the 2 independently predictive measures, yet a beta-blocker at discharge for heart failure is not a NQF or CMS measure. Measures vary in the work necessary to provide the care measured. For example, working with a patient to achieve a hemoglobin $\mathrm{A} 1 \mathrm{c}$ at a certain level requires more effort than ordering preoperative antibiotics. Not all measures have equal value or require similar effort, and the validity of measures will affect the effectiveness of programs that use them for improving heath outcomes as well as quality and efficiency.

The growth in measure development has been accompanied by the development of programs that provide financial incentives for measure reporting and performance. CMS has had a hospital pay-forreporting program that will become a pay-for-performance program this year (2008). ${ }^{12}$ They also initiated a provider pay-for-reporting program in 2007 , which is expected to eventually progress to pay-for-performance. ${ }^{13}$ A 2006 survey of health maintenance organizations found that $90 \%$ had a physician pay-for-performance program. ${ }^{14}$ However, evidence is lacking that financial incentives in the outpatient setting improve health outcomes, particularly in an open or fee-for-service system.

Pay for performance, which is supported by the Medicare Payment Advisory Commission and the IOM, has reached a tipping point, but the concept may be advancing before the science. ${ }^{7,15}$ Although a 2004 systematic review of pay for performance concluded that performance-based payment can improve quality of care, this conclusion was based on 7 trials with mixed results. ${ }^{16}$ A 2006 Congressional Research Service report concluded that there are few rigorous evaluations of the effectiveness of pay-for-performance programs. Initial studies suggest the programs can improve performance on quality measures, but evidence is lacking to support such programs save costs. ${ }^{17}$ A recent study concluded that care dispersion in a fee-for-service program such as Medicare, in which beneficiaries visit multiple physicians in an uncoordinated manner, limits the potential of a pay-for-performance program to improve quality. ${ }^{18}$ The benefit of pay-forperformance programs is unclear, and there may be potential harms.

Pay-for-performance programs may have unintended consequences. Assuming the programs are designed with appropriate attribution and a sufficient incentive, achievement on the program measures may come at an expense. Providers are extremely busy and a new or additional task may supplant another, creating an opportunity cost if the care neglected was of greater value for the individual patient. ${ }^{19}$ If the program uses outcome measures and does not make adjustment for patient confounders such as income, education, health literacy, and comorbidities, providers might select better performing patients for their practice. This may happen especially if the pay-for-performance program leads to provider tiering and networking, in which high-performing physicians receive increased payment or patients have greater cost-sharing through a greater copayment or coinsurance when visiting lower-performing physicians..$^{20}$ Private health plans could further incentivize the highest quality and most efficient providers to take a greater share of their patients, resulting in a reduction of Medicare or Medicaid patients and ultimately leading to a situation in which the poorestperforming providers care for the most vulnerable populations. However, Medicare could compete for these providers by having comparable incentives. Providers who find Medicare or other public pay-for-performance programs overly burdensome relative to the financial return could decrease the number of their patients with such insurance, further worsening access to care. At this point, few of these potential adverse effects have been reported.

Policy often needs to proceed in the absence of definitive evidence, and financial incentives may be an important strategy for improving quality and efficiency. Pilot programs would be useful for increasing knowledge about the effectiveness of different incentive program designs before the imple- 
mentation of a large mandatory program, and some have been promising. Evaluating the unintended and intended effects and sharing best practices will be important to improve financial incentive programs and to maximize value and minimize harm. In the meanwhile, physicians can continue to improve the quality of care provided while being more cognizant of the efficient use of health care resources to improve health outcomes, as well as the accessibility and affordability of health care.

\section{References}

1. Keehan S, Sisko A, Truffer C, et al. Health spending projections through 2017: the baby-boom generation is coming to Medicare. Health Aff 2008;2: W145-55.

2. Emanuel EJ, Fuchs VR. Who really pays for health care? JAMA 2008;299:1057-9.

3. Himmelstein DU, Warren E, Thorne D, Woolhandler S. Illness and injury as contributors to bankruptcy. Health Aff 2005;Suppl Web Exclusives:W563-W5-73.

4. Agency for Healthcare Research and Quality. 2007 National healthcare quality report. Rockville (MD): Agency for Healthcare Research and Quality; 2008.

5. Hayward RA, Kent DM, Vijan S, Hofer TP. Reporting clinical trial results to inform providers, payers, and consumers. Health Aff 2005;24:1571-81.

6. Lohr KN, ed. Medicare: a strategy for quality assurance. Washington, DC: National Academy Press; 1990.

7. Institute of Medicine. Crossing the quality chasm: a new health system for the 21 st century. Washington, DC: National Academies Press; 2001.

8. Evans DB, Tandon A, Murray CJ, Lauer JA. Comparative efficiency of national health systems: cross national econometric analysis. BMJ 2001;323:30710.

9. Agency for Healthcare Research and Quality. Na- tional Quality Measures Clearinghouse [Homepage]. Available at http://www.qualitymeasures.ahrq.gov. Accessed 3 April 2008.

10. National Quality Forum. National Quality Forum [Homepage]. Available at http://www.qualityforum. org. Accessed 3 April 2008.

11. Fonarow GC, Abraham WT, Albert NM, et al. Association between performance measures and clinical outcomes for patients with heart failure. JAMA 2007; 297:61-70.

12. Deficit Reduction Act of 2005, Pub. L. No. 109171, Sec. 5001(b) (January 3, 2006).

13. Tax Relief and Healthcare Act of 2006, Pub. L. No. 109-432, Sec. 101.(b) (January 3, 2006).

14. Rosenthal MB, Landon BE, Normand ST, Frank RG, Epstein AM. Pay for performance in commercial HMOs. N Engl J Med 2006;355:1895-902.

15. Miller ME. Pay for performance in Medicare. Medicare Payment Advisory Commission testimony, 27 July 2005. Available at http://medpac.gov/publications/ congressional_testimony/Testimony_P4P.pdf. Accessed 3 April 2008.

16. Dudley RA, Frolich A, Robinowitz DL, et al. Strategies to support quality-based purchasing: a review of the evidence. Rockville (MD): Agency for Healthcare Research and Quality; 2004.

17. Hahn J. Pay-for-performance in healthcare. Congressional Research Service report for Congress, 2 November 2006. Available at http://www.vascularweb.org/professionals/Government_Relations/PDF_ Doc/CRS\%20report\%20on\%20P4P.pdf. Accessed 3 April 2008.

18. Pham HH, Schrag D, O'Malley AS, Wu B, Bach PB. Care patterns in Medicare and their implications for pay for performance. N Engl J Med 2007;356: 1130-9.

19. Wodchis WP, Ross JS, Detsky AS. Is P4P really FFS? JAMA 2007;298:1797-9.

20. Werner RM, Asch DA. The unintended consequences of publicly reporting quality information. JAMA 2005;293:1239-44. 